\title{
Monitoring Using a Sentinel Plant System Reveals Very Limited Aerial Spread of Phytophthora ramorum From Infected Ornamental Plants in a Quarantine Research Nursery
}

Tomas Pastalka, Department of Natural Sciences and Mathematics, Dominican University of California, San Rafael, CA 94901; Suzanne Rooney-Latham, California Department of Food and Agriculture Plant Pest Diagnostics Lab, Sacramento, CA 95832; Kathleen Kosta, California Department of Food and Agriculture, Sacramento, CA 95814; Karen Suslow and Vernon Huffman, Department of Natural Sciences and Mathematics, Dominican University of California, San Rafael, CA 94901; Sibdas Ghosh, Department of Natural Sciences and Mathematics, Dominican University of California, San Rafael, CA 94901, and School of Arts and Science, lona College, New Rochelle, NY 10801; and Wolfgang Schweigkofler, Department of Natural Sciences and Mathematics, Dominican University of California, San Rafael, CA 94901

Accepted for publication 3 February 2017.

\section{Abstract}

The potential aerial spread of Phytophthora ramorum, causal agent of sudden oak death and Ramorum blight, from infected plants in a quarantine research nursery at the National Ornamentals Research Site at Dominican University of California (NORS-DUC) to the environment was monitored weekly for five years (2011 to 2016) using a sentinel system. Phytophthora ramorum was never detected on any of the sentinel plants (Rhododendron, Viburnum, and Loropetalum spp), indicating very limited aerial spread under suboptimal meteorological and environmental conditions. An infection experiment with host plants placed in the immediate vicinity of symptomatic plants proved the potential for short-distance ( 1 to $2 \mathrm{~m}$ ) aerial transmission of $P$. ramorum. Other Phytophthora spp. causing symptoms similar to $P$. ramorum were detected during the rainy season (January to May) on the sentinel plants, among them potentially two novel species. These data reveal how sentinel monitoring at NORS-DUC allows for seasonal assessments of disease incidence and provide longitudinal data to assess the threat of $P$. ramorum movement in nurseries.
Invasive plant pathogens can cause severe diseases of forest trees, eventually leading to significant economic and environmental damage and possibly even the ecological extinction of native tree species (e.g., Chestnut blight, caused by Cryphonectria parasitica, and Dutch Elm disease, caused by Ophiostoma ulmi). The invasive forest pathogen Phytophthora ramorum Werres, De Cock \& Main in't Veld was detected in the mid-1990s in coastal California (Santa Cruz and Marin counties), and spread quickly through the mixed hardwood-conifer forests of coastal California and southern Oregon, causing extensive mortality of tanoak (Notholithocarpus densiflorus) and coast live oak (Quercus agrifolia) (Rizzo et al. 2002). Airborne sporangia, produced mainly on leaves of tanoaks and California bay laurel (Umbellularia californica) under moist conditions, are responsible for short-distance spread of the disease. Phytophthora ramorum can also infect numerous ornamental plants, among them Rhododendron spp. and Camellia spp., causing foliar symptoms and occasionally branch dieback (Ramorum blight); the nursery trade of infected plants is considered a major pathway for the introduction and long-distance spread of the pathogen. The National Ornamentals Research Site at Dominican University of California (NORS-DUC) in San Rafael, CA, is a field research nursery designed to study quarantine pests and pathogens of ornamentals, with a main focus on P. ramorum and related Phytophthora species, with the mission to examine, develop, and implement control strategies (Johnson-

Corresponding author: Wolfgang Schweigkofler;

E-mail: wolfgang.schweigkofler@dominican.edu

(C) 2017 The American Phytopathological Society
Brousseau et al. 2011). Federal and state regulations require the regular monitoring of potential $P$. ramorum spread through airborne inoculum from the research site to the environment. We developed a sentinel system, consisting of a triple layer of host and nonhost plants laid out along the perimeters of the nursery and within the nursery, to detect symptoms caused by $P$. ramorum and study environmental parameters which might play a role in the spread of the disease.

This project had the following aims: (i) to detect possible movement of $P$. ramorum from the research nursery into the environment ("outbound" movement); (ii) to detect possible movement of $P$. ramorum from the environment into the research nursery ("inbound" movement); (iii) to monitor the development of other biotic diseases which could infect research plants; and (iv) to identify climatic conditions favorable for disease spread.

\section{Layout of a Quarantine Research Site for P. Ramorum}

NORS-DUC was developed to study quarantine pathogens of ornamental plants, particularly $P$. ramorum, under field conditions in a research facility mirroring a commercial nursery. NORS-DUC contains two research sites: site SOUTH is trapezoid-shaped $(40 \times$ $36.5 \times 47 \times 21 \mathrm{~m})$; and site NORTH is rectangular $(65 \times 16 \mathrm{~m})$. The perimeters of both sites are fenced with a single entry point which is equipped with a footbath containing a quaternary ammonium solution for disinfection (AL-SAN 5, Nelson-Jameson, Marshfield, WI) to prevent pathogen movement via contaminated shoes. Each site has six individually contained research plots; within each research plot is a research bed for the experiments. Most research beds are $3.5 \times 9 \mathrm{~m}$ and can be subdivided into two $3.5 \times 4.5 \mathrm{~m}$ 
half-beds. Four research beds are filled with soil (originating from San Rafael, CA) for in-soil experiments, the other eight research beds are used for experiments with potted plants. All research beds are lined with a waterproof pond liner (30 mm thick) to maintain and collect water. The used water is filtered, UV-treated, and monitored for the presence of $P$. ramorum before being released from the research site. Research beds and infected experimental plants are disinfected by steam treatments of $50^{\circ} \mathrm{C}$ for $30 \mathrm{~min}$ after the completion of the project (Schweigkofler et al. 2014).

NORS-DUC is located in San Rafael, Marin Co., CA, an area with a Mediterranean climate characterized by warm, dry summers and mild, rainy winters. Precipitation is restricted mainly to the period from October through April with the wettest months being December through February; the total annual rainfall averages $90 \mathrm{~cm}$. Temperatures below freezing are rare; the average low in the coldest month (December) is $6^{\circ} \mathrm{C}$, and the average high in the warmest month (August) is $27^{\circ} \mathrm{C}$. Prevailing wind direction is $\mathrm{SW}$ with wind speed rarely exceeding $30 \mathrm{~km} / \mathrm{h}$ (Anonymous 2016).

The possible aerial movement of $P$. ramorum from the research beds toward the environment (and vice versa) was monitored using a triple-layered sentinel plant system (Fig. 1). Phytophthora ramorum host plants $(n=145$; primarily Rhododendron $\mathrm{cv}$. 'Cunningham White', 'Boursault', and 'Purple Splendour', but also Camellia spp., Loropetalum chinense, and Viburnum spp. were planted along the outside perimeter of both nursery sites. Leyland cypress (x Cuprocyparis leylandii) $(\mathrm{n}=159)$, a fast-growing evergreen hybrid conifer, were planted outside the fence and behind the host plants to serve as a wind barrier. Cuprocyparis leylandii is susceptible to Phytophthora root rot (caused by $P$. cinnamomi), but is not a proven or associated host of $P$. ramorum. Inside the research plots, a total of 370 potted host plants (mainly Rhododendron and a few Camellia spp.) were used as the third sentinel layer, arranged in groups of five to eight at a distance of 2 to $5 \mathrm{~m}$ to the research bed used for infection experiments. Plants used in the sentinel system were purchased from a nursery operating with a SOD Compliance Agreement and held in quarantine and inspected for disease development over a 6 -week period. Only disease-free plants were included in the sentinel system. Healthy extra plants, which were kept for later use (e.g., to replace infected sentinels) were kept at a holding area $0.3 \mathrm{~km}$ east of the research nursery and also inspected weekly for symptoms. The sentinel and barrier plants were not treated with fungicides to allow for any potential disease development and were drip-irrigated and fertilized following best management practice.

NORS-DUC is a federally funded research facility for researchers across the United States working on $P$. ramorum and other soilborne pathogens under field conditions not allowed in their home research centers due to federal and state regulations. Between 2010 and 2015, numerous projects were carried out at NORS-DUC using infected potted host plants (Rhododendron spp., Camellia spp., Viburnum spp., Quercus agrifolia, Q. rubra, and Umbellularia californica) as well as soil experiments using $P$. ramoruminoculated Rhododendron leaf disks or host-free chlamydospores as inoculum. The experiments focused on a number of scientific questions, including chemical, thermal, and biological control; host-pathogen interaction; and genetic plasticity of $P$. ramorum (Schweigkofler et al. 2014; Funahashi and Parke 2016; Rollins et al. 2015; Kasuga et al. 2016).

Several experiments were conducted by two of our research partners to study the spread of airborne $P$. ramorum inoculum from infected plants. In both cases, Rhododendron plants with P. ramorum leaf symptoms were used as inoculum source. In one experiment, healthy Rhododendron leaf disks were used as baits in plastic cups placed at a distance of 15 and $40 \mathrm{~cm}$ to the inoculum source. In the second experiment, four infected plants were placed in the corner of a research bed, and noninfected Rhododendron plants were placed in several rows around the inoculum source. Whereas the first experiment did not result in any detectable $P$. ramorum spread, the second experiment showed some very limited aerial spread not further than approximately one meter from the inoculum source (B. Knaus and

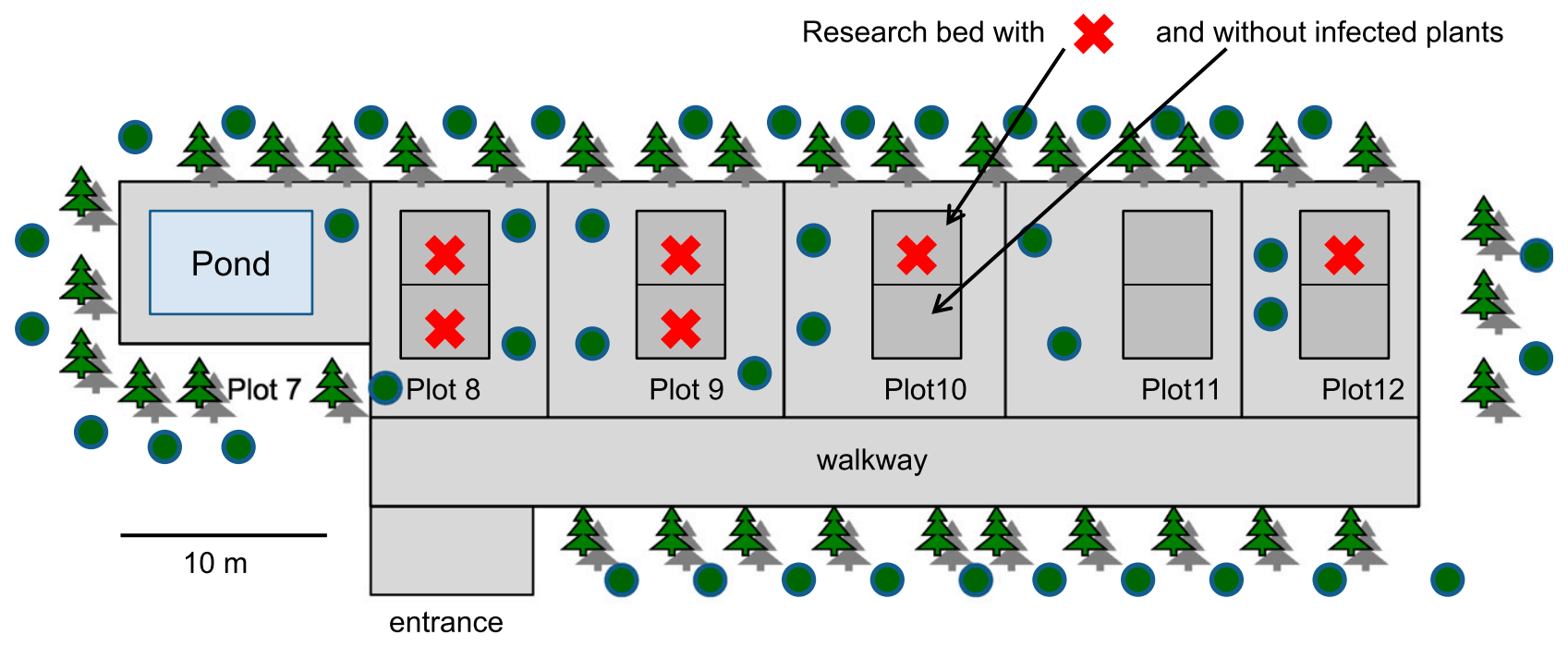

Host plant (Rhododendron, Camellia, Viburnum, Loropetalum)

Barrier plant (x Cuprocyparis leylandii )

FIGURE 1

Layout of the quarantine nursery at NORS-DUC (side NORTH) showing the position of the sentinel plants and research plots with plants infected with Phytophthora ramorum. 
M. Garbelotto, personal communication). In both experiments, the research beds were irrigated overhead to simulate extensive rainfall.

\section{Leaf Symptoms Detected on Sentinel plants}

Leaf symptoms similar to those caused by $P$. ramorum were detected on sentinel plants, mainly from January through May (Fig. 2). Symptomatic leaves were tested for presence of Phytophthora using Agdia Immunostrips (Agdia, Inc., Elkhart, IN); in addition, leaf tissue was placed on Phytophthora selective medium (PARPH-V8; Ferguson and Jeffers 1999) and growing cultures were evaluated microscopically. Selected samples were identified using PCR sequencing of the ITS1, 5.8S rDNA, and ITS2 regions by the California Department of Food and Agriculture Plant Pest Diagnostics Lab (CDFA-PPDC) in Sacramento, CA (White et al. 1990).

Phytophthora ramorum was not detected on any sentinel plants during the five-year monitoring period. The most common fungal group was Pestalotia sp. and its related allies (Pestalotiopsis sp.), ascomycetous fungi belonging to the Xylariales. Pestalotia sp. is considered to be a nonaggressive pathogen of Rhododendron spp., only occasionally causing plant death. Pestalotia sp. was the only pathogen isolated throughout most of the year, including the dry, hot summer months (with the exception of August and October) and was also the only pathogen frequently isolated from sentinels inside the research plots. Young Rhododendron plants developed symptoms caused by Pestalotia commonly on lower leaves and after transplanting and moving to the research plots, potentially a result of being weakened by water stress. Pestalotia sp. was isolated less frequently from well-established Rhododendron sentinels, and also from Eucalyptus trees surrounding the research nursery, which might be a source of inoculum.
Several Phytophthora species were isolated from a total of 55 sentinel plants: $P$. syringae $(\mathrm{n}=32 ; 58.2 \%) ; P$. multivora $(\mathrm{n}=10$; $18.2 \%) ; P$. cf. fallax $(\mathrm{n}=3 ; 5.5 \%) ; P$. hibernalis $(\mathrm{n}=2 ; 3.6 \%) ; P$. cf. boehmeriae ( $\mathrm{n}=1 ; 1.8 \%)$; and a few Phytophthora that were not identified to species level $(\mathrm{n}=7 ; 12.7 \%)$. Phytophthora syringae was detected each year from 2012 to 2016, while $P$. multivora was detected in 2013,2015 , and 2016. A species closely related to $P$. fallax was detected in 2013 and 2014 and a species closely related to P. boehmeriae was detected in 2016. Phytophthora hibernalis was found in 2011 and 2013.

Phytophthora syringae was the most commonly detected species and belongs to Phytophthora clade 8, which also includes $P$. ramorum and $P$. hibernalis. Phytophthora syringae has a rather wide host range and is known to cause foliar spots and blights as well as root and stem rot on Rhododendron, mainly during the winter months. Phytophthora multivora belongs to Phytophthora clade 2 and was originally isolated from Eucalyptus and other tree species in western Australia, but is known also to induce leaf spots on Rhododendron spp. Phytophthora hibernalis is a common species in many nurseries and also causes leaf spots and twig blights on Rhododendron.

Phytophthora boehmeriae (clade 10) is found in Asia, Europe, South Africa, and South America, and is primarily associated with diseases of cotton, citrus, and Eucalyptus spp. There are no reports of it in North America. Although most closely related to P. boehmeriae, our isolate differs by 1 nucleotide in the ITS region and 8 nucleotides in the COX-2 gene, indicating that it might be a novel species. Studies on growth pattern, host range, and molecular taxonomy of the $P$. cf. boehmeriae isolate are ongoing in our lab. The $P$. cf. fallax isolate might also be a new, undescribed species. Phytophthora fallax was originally isolated from crown dieback from several nonnative Eucalyptus spp. in New Zealand (Dick et al. 2006). It belongs to

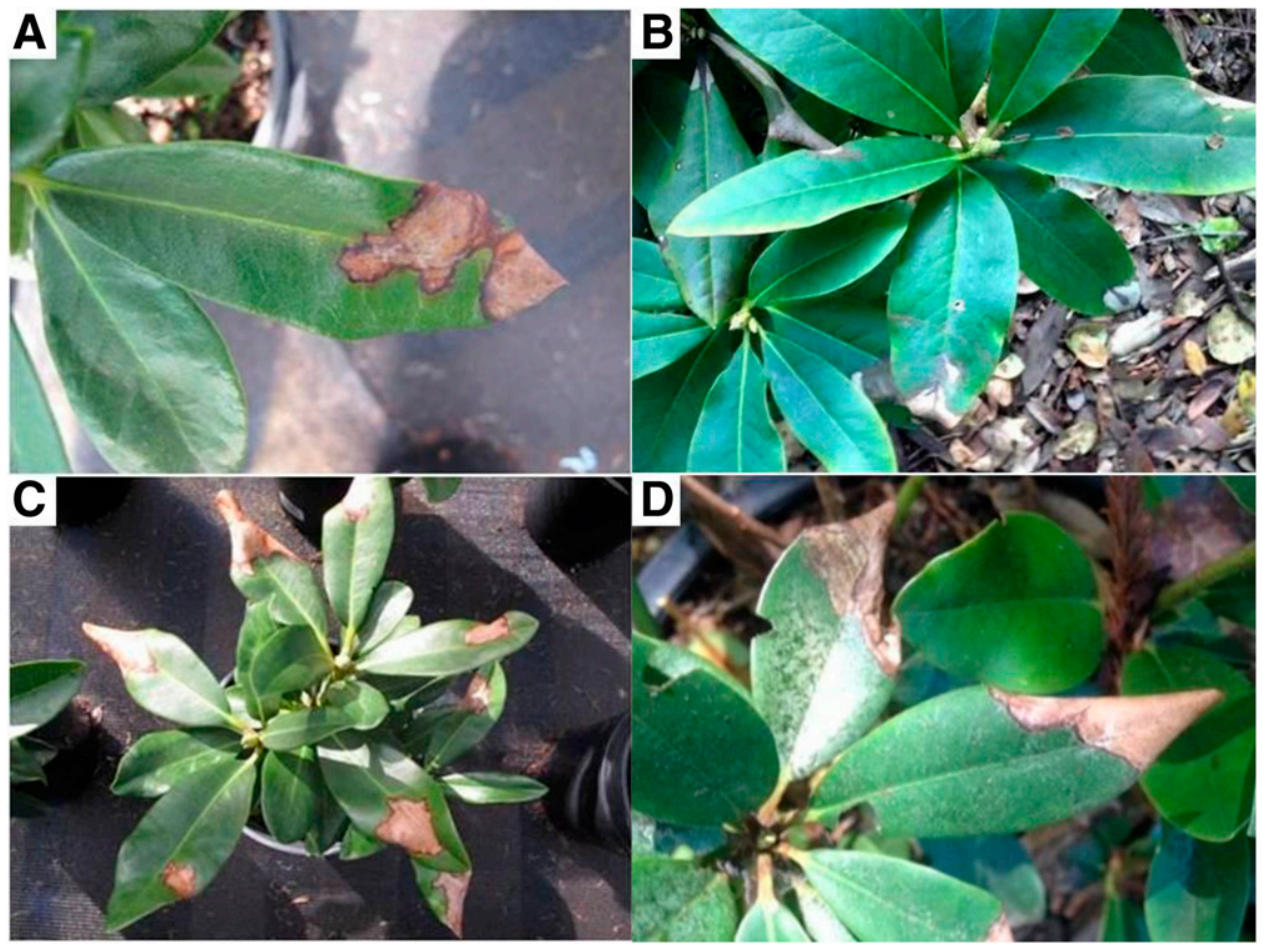

FIGURE 2

Symptoms caused by phytopathogenic oomycetes and fungi on Rhododendron spp.: (A) Phytophthora ramorum on an inoculated plant in the research plot; (B) P. multivora; (C) P. cf. fallax; and (D) Pestalotia sp., on sentinel plants outside the nursery. 
Phytophthora clade 9, a group of mainly aquatic species often found in riparian eco-systems and rarely causing severe plant diseases. The ITS sequences of our isolates differ in four nucleotide positions from that of the $P$. fallax type strain, and therefore the exact taxonomic position is still unclear. Phytophthora cf. fallax seems to be a weak pathogen as inoculation experiments on detached leaves of Rhododendron sp., Camellia sp., Q. agrifolia, U. californica, and Eucalyptus globulus (Blue Gum) did not result in foliar symptoms (data not shown).

The seasonal appearance of leaf symptoms caused by the Phytophthora isolates (January through May) confirms their need for wetness and moderate temperatures (Fig. 3). The number of Phytophthora detections (all species combined) per rainy season from 2011 to 2016 varied from 2 to 20 with the most detections in winter 2015-2016, an El Nino year characterized by significantly higher precipitation than the preceding years. Leaf symptoms appeared predominantly on Rhododendron sentinel plants, and to a lesser extent on Camellia spp.. Viburnum sp. showed occasional symptoms caused by Phoma exigua and Erysiphe viburni (powdery mildew). No leaf symptoms were detected on Loropetalum chinense.

The location of the sentinel plants (within the research plot or lining the outside perimeter) had a clear effect on Phytophthora detection: 49 (89.1\%) Phytophthora detections were made on the
145 plants along the perimeters, and only one (1.8\%) detection was made on the 370 plants within the research plot, indicating that most pathogens originated from areas outside the research nursery (the remaining five isolates were detected in the holding area). Sentinel plants were removed and exchanged with new plants after appearance of symptoms, which might explain the lack of secondary spread from infected "external" sentinel plants to "internal" sentinel plants. Details on the timing and location of symptom detection are shown in Table 1.

\section{Spread of $\boldsymbol{P}$. ramorum from Naturally Infected Bay Laurel Trees to Rhododendrons}

The lack of any detections of $P$. ramorum on the sentinel plants at NORS-DUC could be explained by a number of factors including low inoculum titer or suboptimal, local microclimatic conditions. Using a "natural infection" experiment, we tried to evaluate if different inoculum sources and geographic locations have an effect on transmission. Three potted Rhododendron plants were placed under known $P$. ramorum-infected California bay laurel trees at two different locations. One location was on the campus of Dominican University (DUC), approximately $150 \mathrm{~m}$ east of the research nursery, and the other location was a mixed hardwood/ conifer forest in Mill Valley, in an area within the coastal

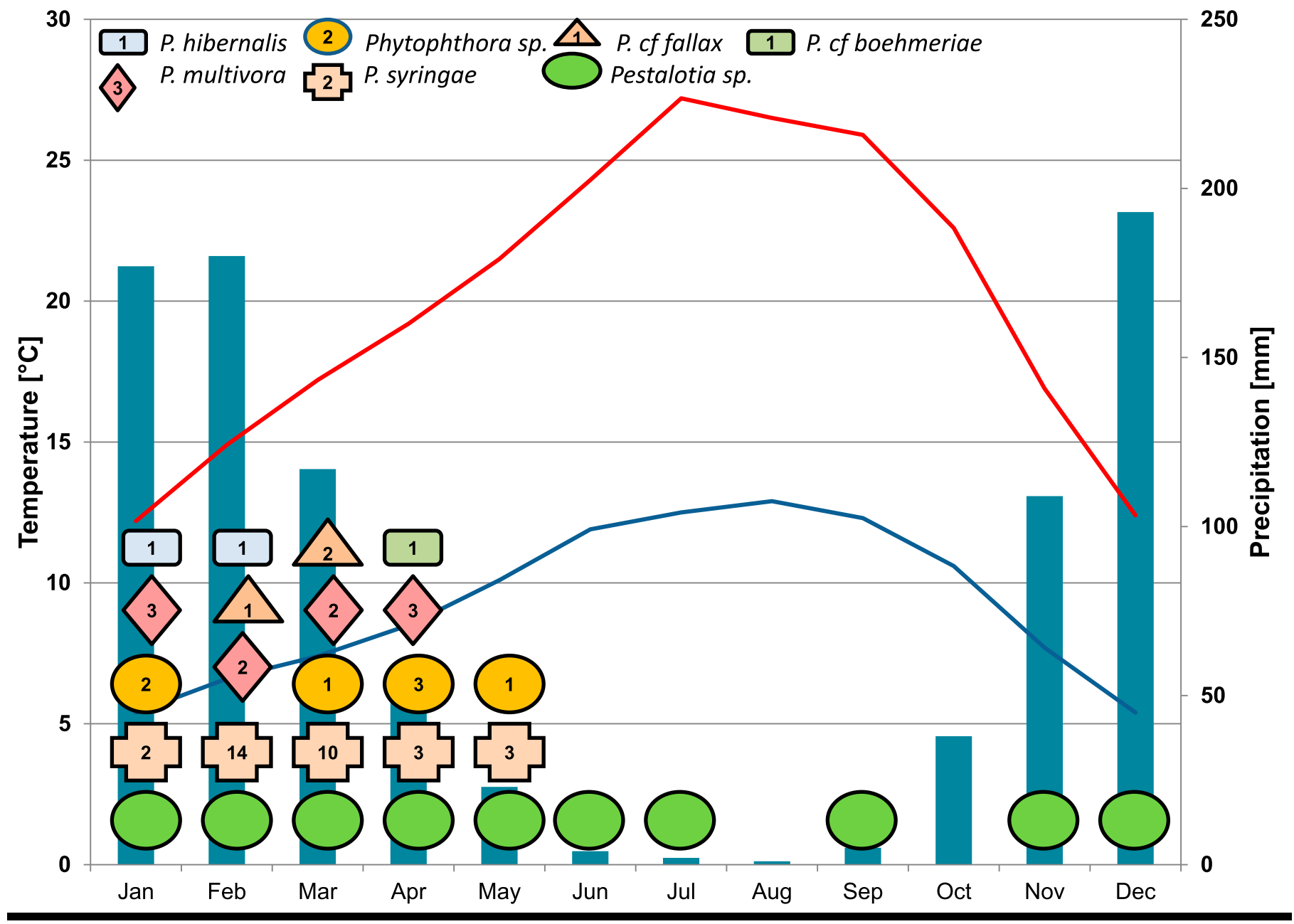

FIGURE 3

Seasonal appearance of symptoms on sentinel plants at NORS-DUC. Numbers indicate how often a Phytophthora species was detected each month (data from 2011 to 2016 were combined). Presence of Pestalotia sp. was not quantified. Meteorological data show the long-term average for San Rafael, CA. 
"fog-belt" heavily infected with $P$. ramorum (Marin Co.; $\sim 10 \mathrm{mi}$ south west of NORS-DUC). The two sites differ significantly in annual average rainfall (San Rafael, $90 \mathrm{~cm}$; Mill Valley, $120 \mathrm{~cm}$ ). The California bay laurel trees and the potted Rhododendron plants were monitored weekly during the rainy season for appearance of $P$. ramorum symptoms; symptomatic leaves were sampled and (if positive for Phytophthora using Immunostrips) plated on PARP-V8 for morphological identification. The experiment was repeated during two rainy seasons (2014-2015 and 2015-2016), starting October 1 in both years.

The results are shown in Fig. 4. In Mill Valley, leaf symptoms caused by $P$. ramorum were present on California bay laurel leaves throughout the monitored period in both years. During the 2014-
2015 season, symptoms on California bay laurel at DUC appeared in early December while they appeared at the end of December during the 2015-2016 season. On Rhododendron, the first symptoms appeared in Mill Valley (on all three plants) and DUC (one out of three plants) on December 15 during the 2014-2015 season. However, during the 2015-2016 season, the first foliar symptoms appeared on Rhododendron in both Mill Valley (on one out of three plants) and DUC (one out of three plants) on January 19. On March 10 , a second Rhododendron showed $P$. ramorum symptoms at DUC. Based on these results we conclude that direct transmission of $P$. ramorum from naturally infected bay trees to Rhododendron is possible under microclimatic conditions typical for the winter months at Dominican University, though the time in which symptoms are

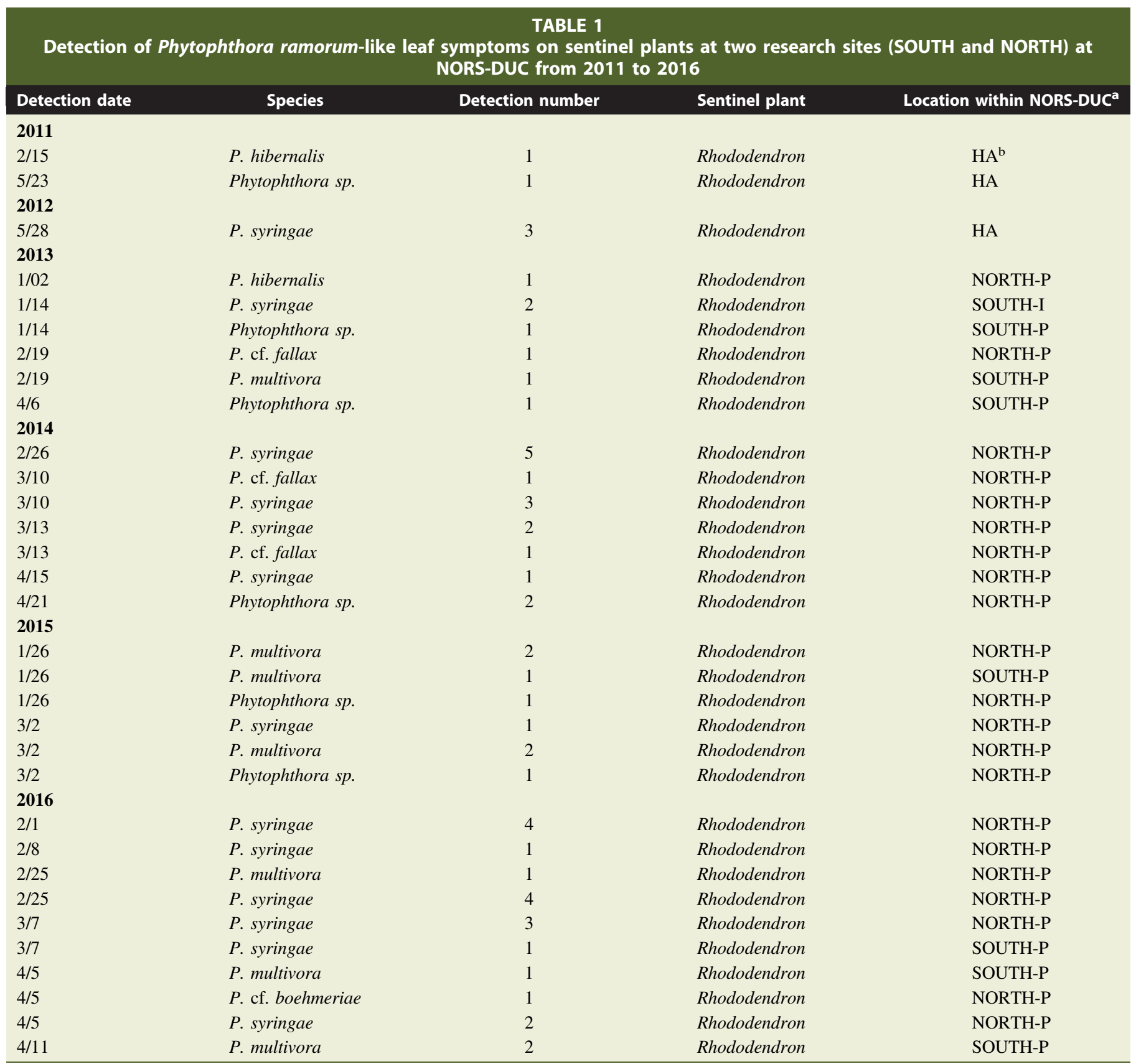

${ }^{\text {a }}$ SOUTH-P and NORTH-P = sentinel plants along the outside perimeters of the two research sites; SOUTH-I = sentinel plants inside the research site. ${ }^{\mathrm{b}} \mathrm{HA}=$ holding area. 
expressed varies yearly depending on environmental parameters. We did not measure the inoculum load of $P$. ramorum on California bay laurel leaves, however, under favorable conditions, a significant proportion of the leaves showed symptoms.

\section{Transmission Experiment Using "Naturally" Infected Rhododendrons}

The spread of $P$. ramorum from symptomatic Rhododendron plants to healthy Rhododendron plants within the research nursery was studied using plants naturally infected in Mill Valley and on the DUC campus (see above). The experiment was repeated during two rainy seasons (winters 2014-2015 and 2015-2016). For the first experiment, three infected plants were moved to the research nursery on 23 December 2014. Nine healthy Rhododendrons were placed around the source of inoculum (0.5- to $1.5-\mathrm{m}$ distance) to simulate conditions at commercial nurseries, where large numbers of cospecific plants are often kept in one big continuous block. After 13 days, Phytophthora symptoms appeared on one Rhododendron plant and after 24 days, symptoms occurred on a second plant (22.2\% transmission rate). Phytophthora ramorum was isolated from both symptomatic leaves on PARP-V8. For the second experiment, three infected plants were moved to the research nursery on 22 January 2016, and 12 healthy Rhododendrons were placed around them (0.5- to $1.5-\mathrm{m}$ distance). Fifty-nine days later, foliar symptoms were detected on five of the 12 Rhododendron plants. After 67 days, symptoms developed on two additional Rhododendron plants and after 87 days, on one additional plant (total of 8 infected plants, $75 \%$ transmission rate). For both experiments, plants were monitored until the following summer (for a total of approximately 200 days) to detect possible delayed spread of $P$. ramorum.

The differences in transmission rates between the two experiments might be related to climatic conditions; the 2014-2015 winter was characterized by some early-season rainfall (October till December), followed by very dry conditions, whereas the 2015-2016 winter (an El Nino year) showed significant rainfall between November and April, but with a month-long dry phase in February. No spread of $P$. ramorum was detected from the infected rhododendron plants in the research bed to the surrounding sentinel plants (minimum distance of $5 \mathrm{~m}$ ).

\section{Aerial Spread of $P$. ramorum Seems to Act Only on Very Short Distances}

While the geographic origin and exact time of intercontinental spread of $P$. ramorum is still unknown, symptoms caused by the pathogen have been identified since the mid-1990s in forests in coastal California and nurseries in northern Europe (Germany and The Netherlands) (Grünwald et al. 2012). Since then, P. ramorum has been spread in European nurseries and gardens by the movement of infected plant material and has not caused significant damage in forests, with the exception of a severe outbreak of $P$. ramorum on commercial plantations of the nonnative Japanese larch (Larix kaempferii) in the United Kingdom in 2009 (Brasier and Webber 2010), and Ireland in 2010. The spread of P. ramorum in North America is quite complex and involves multiple introductions in native forests in California through infected plants or soil, long-distance spread from California to other U.S. states and as well as a few cases of introduction of European isolates into the U.S. (Grünwald et al. 2012). Short-distance spread of $P$. ramorum is mainly caused by airborne sporangia, which are produced in high numbers on leaves of California bay laurels and tanoaks under moist and mild weather conditions.

Multiyear surveys from the California SOD Blitz, a citizen scientist project involving hundreds of volunteers to sample SOD symptoms each spring since 2008 and organized by researchers at UC Berkeley (Meentemeyer et al. 2015), support the idea that $P$. ramorum spread is very limited during years with average and below-average rainfall in coastal California, and that the main driver for the expansion of the disease range is wetter than average winters. The rather large sporangia size (length $\times$ width $=25$ to $97 \times 14$ to $34 \mu \mathrm{m}$, mean 46 to $65 \times 21$ to $28 \mu \mathrm{m}$ ) indicates that $P$. ramorum might not be carried very well through air currents. Rain droplets (splash) or running water may play a more important role in short-distance transmission. Phytophthora ramorum is routinely baited from creeks and rivers in infested landscapes and forests; recirculated irrigation water in nurseries has also been shown to play a role in the infection process of healthy container plants (Werres et al. 2007). Our work has shown that $P$. ramorum can be detected from recirculated water in the NORS-DUC site as well as a seasonal creek on the DUC campus (data not shown).

Nurseries often are characterized by the presence of high plant diversity on a small area and conditions that are favorable for pathogen introduction and spread (e.g., movement of plant material between nurseries, over-head and extensive irrigation, use of recycled water), making them an ideal habitat for many Phytophthora species (Junker et al. 2016, Parke et al. 2014). Different niches within the nursery (soil, water, plants) can be colonized by different Phytophthora species, and both species composition and abundance can undergo seasonal fluctuations.

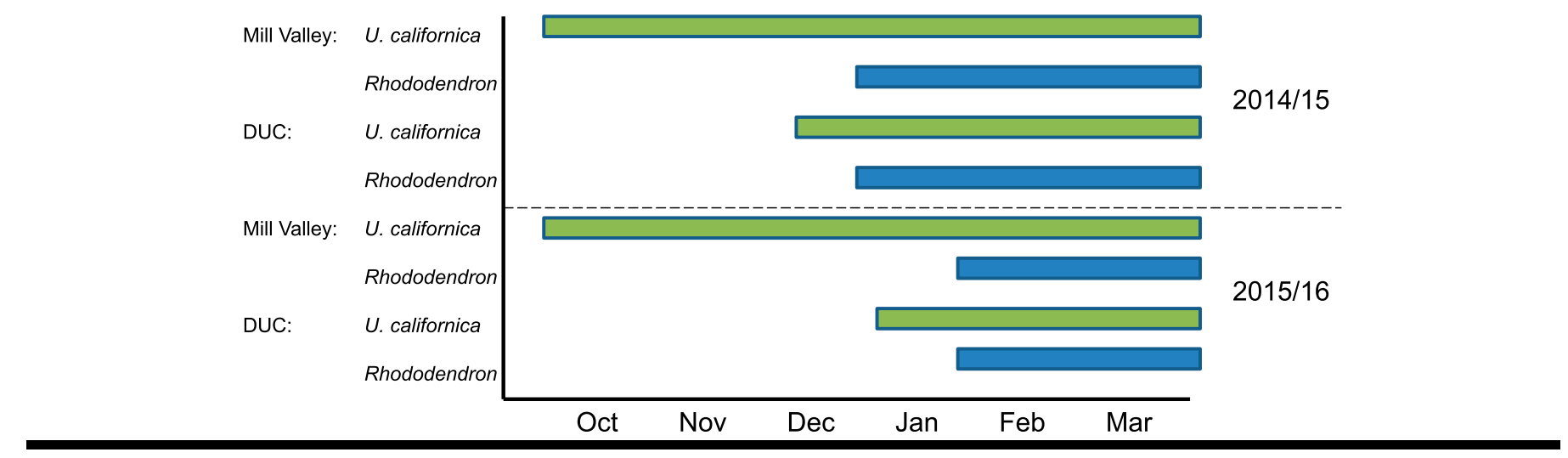

FIGURE 4

Symptom expression of Phytophthora ramorum on California bay laurel (green bars) and Rhododendron spp. (blue bars) at two locations (Mill Valley and Dominican University campus). 
NORS-DUC is the only quarantine research nursery in the United States established to conduct mock field experiments with $P$. ramorum under the oversight of USDA-APHIS. Inoculation experiments at the research site impose the risk of pathogen escape into the environment. To mitigate the risks, NORS-DUC was built in Marin Co., an area with many mixed hardwood/conifer forests already heavily infected with $P$. ramorum. In addition, the sentinel system was established to monitor possible aerial movement of $P$. ramorum from the site. Sentinel plants have been used to monitor aerial spread of pollen of genetically modified crops (Watrud et al. 2004), pesticides (Felsot et al. 1996), and invasive plant pathogens (Sanatkar et al. 2015). An international project was initiated recently to use botanic gardens and arboreta worldwide to detect potential invasive pathogens and pests before they spread to new environments (Britton et al. 2010), and a similar approach was used to forecast potential invasions of alien plant pathogens from China to Europe with the planting of European hardwood trees (Quercus sp.) in southeastern China (Vettraiano et al. 2015). To our knowledge, our study is the longest-running sentinel monitoring program of a quarantined forest pathogen.

During a five-year period (2011-2016), we did not detect any $P$. ramorum infections in our sentinel plants within and outside the two research sites. Due to the highly diverse experiments conducted at NORS-DUC from 2011 to 2015 by different researchers (e.g., use of different host plants; inoculation of potted plants and soil; different inoculum type) it was not possible to estimate the amount of aerial $P$. ramorum inoculum present at the research site during that period. However, infected and symptomatic plants were present throughout most of the reported time, including the rainy winter months when most $P$. ramorum spread occurs in natural environments. Phytophthora ramorum requires a moist period of $\sim 24 \mathrm{~h}$ for sporulation on Rhododendron 'Cunningham's White', and spore production is highest at temperatures between 15 and $20^{\circ} \mathrm{C}$. While the environmental requirements of $P$. ramorum are similar to other Phytophthora species, $P$. ramorum produces sporangia more slowly than some of them (Tooley and Browning 2015). The local microclimatic conditions at NORS-DUC, with considerably less fog and more sun hours than the coastal areas mainly affected by SOD, are suboptimal for high inoculum production during the California drought years, but still not preventive for limited disease spread, as shown by regular outbreaks of $P$. ramorum symptoms on California bay laurel trees on campus. The results of our transmission experiment indicate that horizontal aerial spread of $P$. ramorum might be limited to a few meters under our local conditions, and support existing best management practice guidelines developed to minimize the risk of $P$. ramorum spread in commercial nurseries (Anonymous 2008), such as the creation of a physical barrier or a 2-m break between high-risk plants and all other crops as well as breaking up long sections of host and associated plants (HAP) with non-HAP material.

Based on cumulative results over a five-year period we consider the risk of aerial spread of $P$. ramorum from infected plants used at NORS-DUC into the environment as low. The usefulness of the sentinel system for early detection of pathogens was confirmed by the repeated isolation of multiple other Phytophthora spp., including $P$. cf. fallax and $P$. cf. boehmeriae, two likely novel species with unknown host ranges. The observed effect of seasonality on pathogen detection, resulting in Phytophthora detection only in late winter and spring, can be used to develop more efficient strategies for nursery surveys by timing them accordingly.

\section{Acknowledgments}

We thank Dr. Sheila Johnson-Brousseau, Michael Henkes, and Glenn Copeland for the assistance in the design and development of NORS-DUC and the initial stage of this project. The National Ornamentals Research Site at the Dominican University of California is funded by grants from the 2008 and 2014 Farm Bills, and administrated through the United States Department of Agriculture (USDA) Animal and plant Health Inspection Service (APHIS) Plant Protection and Quarantine (PPQ) Center for Plant Health Science and Technology (CPHST).

\section{Literature Cited}

Anonymous. 2008. Nursery industry best management practices for Phytophthora ramorum to prevent the introduction or establishment in California nursery operations. Calif. Assoc. of Nurseries and Garden Centers, Sacramento. http://cangc.org/public/downloads/cangc_bpm.pdf

Anonymous. 2016. University of California Agriculture and Natural Resources California Weather Database for Point San Pedro, San Rafael, CA http://ipm. ucanr.edu/calludt.cgi/WXSTATIONDATA?STN=Point_San_Pedro.A

Brasier, C., and Webber, J. 2010. Sudden larch death. Nature 466:824-825.

Britton, K. O., White, P., Kramer, A., and Hudler, G. 2010. A new approach to stopping the spread of invasive insects and pathogens: early detection and rapid response via a global network of sentinel plantings. N. Z. J. For. Sci. 40:109-114.

Dick, M. A., Dobbie, K., Cooke, D. E. L., and Brasier, C. M. 2006. Phytophthora captiosa sp. nov and P-fallax sp. nov causing crown dieback of Eucalyptus in New Zealand. Mycol. Res. 110:393-404.

Felsot, A. S., Bhatti, M. A., Mink, G. A., and Reisenauer, G. 1996. Biomonitoring with sentinel plants to assess exposure of nontarget crops to atmospheric deposition of herbicide residues. Environ. Toxicol. Chem. 15: 452-459.

Ferguson, A. J., and Jeffers, S. N. 1999. Detecting multiple species of Phytophthora in container mixes from ornamental crop nurseries. Plant Dis. 83: 1129-1136.

Funahashi, F., and Parke, J. L. 2016. Effects of Soil Solarization and Trichoderma asperellum on Soilborne Inoculum of Phytophthora ramorum and Phytophthora pini in Container Nurseries. Plant Dis. 100:438-443.

Grünwald, N. J., Garbelotto, M., Goss, E. M., Heungens, K., and Prospero, S. 2012. Emergence of the sudden oak death pathogen Phytophthora ramorum. Trends Microbiol. 20:131-138.

Johnson-Brousseau, S., Henkes, M., Kosta, K., Suslow, K., Posadas, A., and Ghosh, S. 2011. Phytophthora ramorum research at the National Ornamental Research site at the Dominican University of California. N. Z. J. For. Sci. 41S: 101-113.

Junker, C., Goff, P., Wagner, S., and Werres, S. 2016. Occurrence of Phytophthora in commercial nursery production. Plant Health Prog. 17: 64-75.

Kasuga, T., Bui, M., Bernhardt, E., Swiecki, T., Aram, K., Cano, L. M., Webber, J., Brasier, C., Press, C., Grünwald, N. J., Rizzo, D. M., and Garbelotto, M. 2016. Host-induced aneuploidy and phenotypic diversification in the Sudden Oak Death pathogen Phytophthora ramorum. BMC Genomics 17:385.

Meentemeyer, R. K., Dorning, M. A., Vogler, J. B., Schmidt, D., and Garbelotto, M. 2015. Citizen science helps predict risk of emerging infectious disease. Front. Ecol. Environ 13:189-194.

Parke, J. L., Knaus, B. J., Fieland, V. J., Lewis, C., and Grünwald, N. J. 2014. Phytophthora community structure analyses in Oregon nurseries inform systems approaches to disease management. Phytopathology 104:1052-1062.

Rizzo, D. M., Garbelotto, M., Davidson, J. M., Slaughter, G. W., and Koike, S. T. 2002. Phytophthora ramorum as the Cause of Extensive Mortality of Quercus spp. and Lithocarpus densiflorus in California. Plant Dis. 86: 205-214.

Rollins, L., Elliott, M., and Chastagner, G. 2015. A new method to apply Phytophthora ramorum inoculum to hosts that simulates overhead irrigation. Plant Health Prog. 16:100-106.

Sanatkar, M. R., Scoglio, C., Natarajan, B., Isard, S. A., and Garrett, K. A. 2015. History, epidemic evolution, and model burn-in for a network of annual invasion: soybean rust. Phytopathology 105:947-955.

Schweigkofler, W., Kosta, K., Huffman, V., Sharma, S., Suslow, K., and Ghosh, S. 2014. Steaming inactivates Phytophthora ramorum, causal agent of sudden oak death and ramorum blight, from infested nursery soils in California. Plant Health Prog. 15:43-47.

Tooley, P. W., and Browning, M. 2015. Temperature effects on the onset of sporulation by Phytophthora ramorum on Rhododendron 'Cunningham's White'. J. Phytopathol. 163:908-914. 
Vettraino, A. M., Roques, A., Yart, A., Fan, J.-T., Sun, J.-H., and Vannini, A. 2015. Sentinel trees as a tool to forecast invasions of alien plant pathogens. PLoS One 10:e 0120571.

Watrud, L. S., Lee, E. H., Fairbrother, A., Burdick, C., Reichman, J. R., Bollman, M., Storm, M., King, G., and Van de Water, P. K. 2004. Evidence for landscape-level, pollen-mediated gene flow from genetically modified creeping bentgrass with CP4 EPSPS as a marker. PNAS 101(40):14533-14538.
Werres, S., Wagner, S., Brand, T., Kaminski, K., and Seipp, D. 2007. Survival of Phytophthora ramorum in recirculating irrigation water and subsequent infection of Rhodendron and Viburnum. Plant Dis. 91:1034-1044.

White, T. J., Bruns, T., Lee, S., and Taylor, J. 1990. Amplification and direct sequencing of fungal ribosomal RNA genes for phylogenetics. Pages 315-322 in: PCR Protocols: a Guide to Methods and Applications, Chapter 38. Academic Press, Orlando, Florida. 